Brit. J. industr. Med., 1960, 17, 149.

\title{
THE FAILURE OF ABSORPTION OF DC SILICONE FLUID 703 FROM THE GASTROINTESTINAL TRACT OF RATS
}

\author{
BY \\ J. PAUL* and W. F. R. POVER \\ From the Department of Medical Biochemistry and Pharmacology, the University, Birmingham, 15
}

(RECEIVED FOR PUBLICATION AUGUST 24, 1959)

The intestinal absorption of silicone fluid 703, a methyl phenyl polysiloxane, has been studied in the rat. This silicone was chosen for the present investigation because of its lipid-like character and its solubility in olive oil.

The experimental findings demonstrate that very little, if any, silicone is absorbed when fed in olive oil. No silicone was found in the lymph lipids of cannulated rats fed the silicone, and balance experiments by recovery of the organosilicon compound and triglyceride after feeding to rats for three hours showed that $85 \%$ of silicone fluid 703 was recovered from the gastrointestinal tract, whereas $70 \%$ of the fed triglyceride was absorbed. The unabsorbed silicone was concentrated chiefly in the intestinal lumen. Balance experiments by recovery of the organosilicon compound after long-term feeding gave recoveries of $96 \%$ of the silicone. This amount was recovered entirely from the lower part of the gastrointestinal tract and the faeces. No silicon fluid 703 was found in the liver, kidneys, or fat depots. The urine contained no soluble silica.

The increasing use of various silicones for lubricating baking pans and surgical appliances, as antifoaming agents in the manufacture of sugar, beverages, wine, chewing-gum base, drugs, and cosmetics have led several workers (Rowe, Spencer, and Bass, 1948; Kern, Anderson, and Harris, 1949; Largett, Blackstone, and Roth, 1950; Child, Paquin, and Deichmann, 1951; Cutting, 1952) to study the toxicity of this class of compounds. Most of the experimental work has been the feeding of DC silicone fluids 200 and 555 and DC antifoam A.

In all cases the silicones do not exhibit any significantly harmful effects in the rat and dog. These findings were based on long-term feeding experiments of the silicones to experimental animals followed by gross and microscopic examinations of the more important organs of the animals together with examination of the stool, urine, and blood in some cases.

It is possible in the interpretation of the earlier results that no significant toxic effects were produced because of the lack of absorption of the silicones from the intestines and that their elimination

\footnotetext{
* Present address: The Government Analyst Department, Georgetown, British Guiana, South America.
}

may be too rapid to cause any toxic effects to become evident. Indeed, Drill (1954) reported that when dogs were fed high doses of "DC antifoam $A$ " the silicone was recovered quantitatively from the stool.

The investigation reported here is a study of the absorption of DC silicone fluid 703, a methylphenyl polysiloxane, from the gastrointestinal tract of rats.

There is experimental evidence that some lipidlike materials other than triglyceride fats are rapidly absorbed from the gastrointestinal tract when they are fed dissolved in a triglyceride vehicle (Bloom, Chaikoff, Reinhardt, Entenman, and Dauben, 1950; Daniel, Frazer, French, and Sammons, 1951; Borgström, 1951; Kim and Ivy, 1952). Absorption may not occur when they are fed alone (Ahmad, 1931; Cook, 1936). For such lipid-like materials the important prerequisite for their absorption is that they should be fed dissolved in an oil vehicle. Since only the methylphenyl polysiloxanes are oilsoluble (the methyl polysiloxanes being insoluble in olive oil) and because of their lipid-like character with respect to their behaviour in organic solvents, it was thought that for the proper study of the absorption of the polysiloxanes, silicone fluid 703 should be chosen for such studies. 
Materials

DC Silicone fluid 703 was presented by Midland Silicones, Ltd. For animal experiments, male albino rats between 200 and $250 \mathrm{~g}$. in weight were used. The animals were maintained on an unrestricted diet of rat cake and water, but 24 hours before acute feeding experiments they were starved.

\section{Experimental Methods}

Estimation of Organosilicon Compound in Gastrointestinal Lipid.-The organosilicon compound was estimated by determination of its silicon content. This involved the conversion of the organosilicon compound into soluble sodium silicate by sodium peroxide fusion in a Parr-bomb (Parr, 1908, 1919), followed by estimation of the soluble silicate by the formation of molybdenum blue (Foulger, 1927) which was estimated colorimetrically. The interference of phosphate was reduced to insignificance by the addition of oxalic acid (Schwartz, 1941). The composition of the reagents found to give accurate and reproducible results for the colorimetric estimation of the soluble silica is given below in the order in which the reagents were added.

$2 \mathrm{ml}$. solution of fused residue (approximately $30 \mu \mathrm{g} . \mathrm{Si})$

$2 \mathrm{ml}$. N hydrochloric acid

$4 \mathrm{ml}$. 10\% ammonium molybdate solution (tetrahydrate)

$2 \mathrm{ml} .10 \%$ oxalic acid solution (dihydrate)

$4 \mathrm{ml} .30 \%$ sodium sulphite solution (heptahydrate) Compensation for colour formation caused by the reagents was obtained by making reference solutions in which $2 \mathrm{ml}$. distilled water was used and the reagents added in the sequence already described.

Estimation of Soluble Silica in Urine.-Soluble silica in urine was determined by the method of Paul and Pover (1959). This involved the selective extraction of phosphomolybdate from silicomolybdate by ethyl acetate, and subsequent colorimetric determination of the silicomolybdate as molybdenum blue by reduction with $30 \%$ sodium sulphite solution.

Infra-red Absorption Spectra.-All infra-red absorption spectra were recorded on a single beam instrument.

Cannulation of Rats.-The intestinal lymphatic duct was used as a source of chyle. The animals were maintained on a normal diet of rat cakes and water before operation. Cannulation of the intestinal lymphatic duct was by Tasker's (1951) modification of the original method by Bollman, Cain, and Grindlay (1948). After the operation the cannulated animals were starved for 12 hours and then fed $0.65 \mathrm{ml}$. of a $15 \%$ solution of DC silicone fluid 703 in olive oil, the solution being coloured by the addition of $\beta$-brown ( $\beta$-naphthaleneazo- $\beta$-naphthol), a dyestuff known to be absorbed by the lymphatic pathway. Chyle was collected at intervals of three hours, and the coloured fractions indicating maximum absorption were pooled and extracted for DC silicone fluid 703.

Extraction of DC Silicone Fluid 703 from Chyle.-
The pooled chyle was added to 40 times its volume of 3: 1 absolute alcohol/diethyl ether mixture and filtered through a finely meshed sintered funnel. The filtrate was reduced by means of a rotary evaporator maintained at $37^{\circ} \mathrm{C}$. The residue was dissolved in a small volume of petroleum ether (b.p. $40-60^{\circ} \mathrm{C}$.) and filtered. The solvent was allowed to evaporate at room temperature and the weight of the residue determined. A weighed portion of this was then fused in a Parr-bomb and its silicon content determined colorimetrically. This method of extraction of lymph lipids was shown to be $97.5 \%$ efficient.

Acute Feeding Experiments (Three and a half Hours).The experimental animals were fed $0.65 \mathrm{ml}$ of DC silicone fluid 703 in olive oil by intubation. After three and a half hours the animals were sacrificed. Ligatures were placed at the ileocaecal valve, the pyloric sphincter, and the cardiac sphincter. The oesophagus was cut above the ligature, and the stomach, small and large intestines removed, the colon being incised below the caecum. The stomach, intestine, and caecum were separated and their lipid content extracted as described for each organ below.

Stomach.-The stomach was slit open along the midventral curvature. The contents were washed with petroleum ether (b.p. $40-60^{\circ} \mathrm{C}$.) into a $50 \mathrm{ml}$. bolthead flask. These washings were evaporated to dryness. The residue was again taken up into petroleum ether (b.p. $40-60^{\circ} \mathrm{C}$.) and filtered into a weighed bolthead flask. The solvent was removed by heating on a steam bath. The residue was weighed and examined for silicon.

Intestine.-A syringe was inserted into the distal end of the ileum while the proximal end was placed in a $50-\mathrm{ml}$. bolthead flask. The whole length of the intestine was then flushed through with two successive volumes of $4 \%$ formal isotonic saline solution, followed by gentle massaging along the whole length of the intestine with the thumb and forefinger and again with a further quantity of $4 \%$ formal saline solution. The contents of the flask were taken to dryness by heating in an oven maintained at $60^{\circ} \mathrm{C}$. After cooling the flask, the residue was extracted with petroleum ether (b.p. $40-60^{\circ} \mathrm{C}$.). The petroleum ether solution was filtered into a weighed flask and after removal of the solvent on a hot-water bath and allowing the flask to cool to room temperature, the residue was weighed and examined for silicon.

Caecum.-The caecum was slit open mid-ventrally and its contents washed through a funnel into a $50-\mathrm{ml}$. bolthead flask, with $4 \%$ formal isotonic saline solution from a wash bottle. The method of extraction of the lipid and lipid-soluble materials was the same as that described for the extraction of the intestinal lipids.

Long-term Feeding Experiments.-Rats starved 24 hours before feeding experiments were put on the experimental diet for a period of eight days. This diet consisted of the following :-

Rat cake powder compounded by Messrs. Heygate and Sons, $\begin{array}{lr}\text { Ltd. } & (80 \% \text { of the total diet) } \\ \text { Olive oil } & (16 \% \text { of } t . \text { e total diet) } \\ \text { DC silicone fluid } 703 & (4 \% \text { of the total diet) }\end{array}$ 
The silicone fluid was dissolved in the triglyceride before mixing.

Control diets consisted of rat cake powder and olive oil only.

The animals were housed in separate metabolism cages and maintained on control and experimental diets on a daily feed of $15 \mathrm{~g}$. to each animal. Water was allowed ad libitum. The faeces were collected on a wire mesh tray and urine separately through a funnel into polythene beakers containing liquid paraffin. The faeces and urine for each rat were collected daily but pooled.

At the end of the experiment the animals were starved for 24 hours after which they were killed. The lipid and lipid-soluble materials from the gastrointestinal tract were extracted as described before, while the liver, kidneys, and fat depots from each rat were dissected and the lipid content of each extracted and examined individually for silicone fluid 703 .

The trays were washed with petroleum ether (b.p. $40-60^{\circ} \mathrm{C}$.), the solvent evaporated and the weight of the spilled food determined. Food bins were weighed and the amount of food eaten by each rat calculated.

Extraction of Lipid and Lipid-soluble Materials from Faeces.-The extraction of faecal lipids was by the method of Bentley (1955). The faeces were dried at $60^{\circ} \mathrm{C}$. in an oven and then boiled for 15 minutes with $100 \mathrm{ml}$. normal hydrochloric acid. After cooling, the lipid material was extracted with an equal volume of petroleum ether (b.p. $40-60^{\circ} \mathrm{C}$.). Any emulsion formed was broken down by centrifugation. The ethereal fraction was separated and the extraction procedure repeated twice. The extracts were combined and dried over anhydrous sodium sulphate. After filtration, the petroleum ether was removed on a hot water bath and the residue weighed. The silicon content of this material was then determined.

Extraction of Lipid and Lipid-soluble Materials from Liver, fat depots, and Kidneys.-The liver, kidneys, and fat depots of each animal were dissected and homogenized separately in $25 \mathrm{ml}$. of $30 \%$ diethyl ether/absolute alcohol mixture by means of a Waring blender. The solvent was evaporated on a hot water bath. The dry residue was treated with petroleum ether (b.p. $40-60^{\circ} \mathrm{C}$.) and the solid material carefully broken up with a nickel spatula. The solvent was filtered into a $50-\mathrm{ml}$. bolthead flask and the residue re-extracted twice. The extracts were combined and after removal of the solvent by heating on a hot water bath, the residue weighed. A portion of the residue after extraction of each organ was fused with peroxide and its silicon content determined.

The lipid residues obtained from the liver of each rat were combined, weighed, and redissolved in $10 \mathrm{ml}$. petroleum ether (b.p. $40-60^{\circ} \mathrm{C}$.). This solution was passed down an $18 \times 2 \mathrm{~cm}$. alumina chromatograph column to remove phospholipids. The column was eluted by further quantities of petroleum ether (b.p. $40-60^{\circ} \mathrm{C}$.). Silicone fluid 703 dissolved in petroleum ether $\left(40-60^{\circ} \mathrm{C}\right.$.) is not held on an alumina column and all is eluted in the first $25 \mathrm{ml}$. of petroleum ether.

The lipid residues from the fat depots of each rat were combined, weighed and saponified for 17 hours with
$25 \mathrm{ml}$. of a $20 \%$ alcoholic $\mathrm{KOH}$ solution. After cooling, the alcoholic solution was acidified and extracted with petroleum ether (b.p. $40-60^{\circ} \mathrm{C}$.) and re-extracted twice with further portions of the solvent. The ethereal extracts were combined and dried over anhydrous sodium sulphate. This was filtered and then the solvent removed by heating on a hot water-bath. The residue was weighed, redissolved in $10 \mathrm{ml}$. petroleum ether, and chromatographed as before. This removes fatty acids. Elution of the column was by petroleum ether, after which the solvent was removed and the residue weighed. A portion of this residue was examined for silicone fluid 703.

\section{Results}

The amount of silicon in the reagents used in the Parr-bomb as fusion materials was low (Table 1),

TABLE 1

DETERMINATION OF OPTICAL DENSITIES OBTAINED FROM REAGENTS AND FAT VEHICLE

\begin{tabular}{l|c|c}
\hline \multicolumn{1}{c|}{ Compounds } & Weight Fused (mg.) & Optical Density \\
\cline { 2 - 3 } Fusion mixture alone & 1,600 & 0.010 \\
& $\begin{array}{c}\text { (100 sucrose, 1,500 } \\
\text { sodium peroxide) }\end{array}$ & 0.020 \\
& & 0.019 \\
Fusion with lipids & 60.8 & 0.005 \\
Olive oil & 52.5 & 0.061 \\
& 38.3 & 0.051 \\
Fasting chyle lipid & 58.2 & 0.056 \\
& 31.8 & 0.061 \\
Egg phospholipid & 63.1 & 0.063 \\
& 51.6 & 0.051 \\
Rat cake powder & 27.1 & 0.056 \\
& 66.8 & 0.064 \\
& 63.6 & 0.053 \\
An organosilicon com- & 68.9 & 0.032 \\
pound (trimethyl hexa- & 92.1 & 0.051 \\
decyl silane) & 60.4 & 0.032 \\
& 14.9 & 0.032 \\
& 16.0 & 0.569 \\
& 15.1 & 0.585 \\
\end{tabular}

and in an organosilicon compound, the method of estimation was accurate to within $98 \%$ (Table 2).

TABLE 2

REPRODUCIBILITY OF SILICON DETERMINATION IN TRIMETHYL HEXADECYL SILANE TO DEMONSTRATE
ACCURACY OF COLORIMETRIC METHOD OF SILICON ESTIMATION

\begin{tabular}{c|c|c|c}
\hline $\begin{array}{c}\text { Weight of } \\
\text { Organosilicon } \\
\text { Compound } \\
\text { Fused (mg.) }\end{array}$ & $\begin{array}{c}\text { Theoretical } \\
\text { Silicon } \\
\text { Content (mg.) }\end{array}$ & $\begin{array}{c}\text { Estimated } \\
\text { Silicon } \\
\text { Content (mg.) }\end{array}$ & $\begin{array}{c}\% \\
\text { Error }\end{array}$ \\
\hline 28.6 & 2.69 & 2.68 & 0.4 \\
31.4 & 2.95 & 2.89 & 2.0 \\
28.9 & 2.72 & 2.68 & 1.5 \\
29.3 & 2.75 & 2.75 & 0.0 \\
44.4 & 4.17 & 4.08 & 2.2 \\
58.0 & 5.45 & 5.37 & 1.5 \\
30.7 & 2.89 & 2.90 & 0.4 \\
28.7 & 2.71 & 2.68 & 1.1 \\
\hline
\end{tabular}

Mean $\%$ error $=1.14 \pm 0.8$.

Fusion of fasting chyle lipid and egg phospholipid by the peroxide bomb method, followed by the colorimetric estimation, gave results which were 
TABLE 3

RECOVERY OF LIPID AND SILICON FROM INTESTINAL WASHINGS TO SHOW RELIABILITY OF EXTRACTHN PROCEDURE

\begin{tabular}{|c|c|c|c|c|}
\hline Weight Lipid Fused (mg.) & $\begin{array}{c}\text { Total } \\
\text { Weight } \\
\text { Lipid Recovered (mg.) }\end{array}$ & $\begin{array}{c}\text { Recovered } \\
\text { by Total } \\
\text { Lipid Weight }\end{array}$ & $\begin{array}{c}\text { Total } \\
\text { Silicon Content } \\
\text { (mg.) }\end{array}$ & $\begin{array}{c}\text { \% Recovered } \\
\text { by Silicon Estimation } \\
\text { Method }\end{array}$ \\
\hline $\begin{array}{l}24.0 \\
30.0 \\
30.5 \\
30.0 \\
22.6 \\
30.4 \\
22.7 \\
24.3\end{array}$ & $\begin{array}{l}573.8 \\
566.6 \\
562.6 \\
541.6 \\
566.6 \\
588.7 \\
563.2 \\
579.5\end{array}$ & $\begin{array}{l}93.6 \\
92.4 \\
91.8 \\
88.4 \\
92.4 \\
96.0 \\
91.9 \\
94.5\end{array}$ & $\begin{array}{l}35.6 \\
35.1 \\
34.0 \\
33.0 \\
35.1 \\
36.1 \\
34.8 \\
35.5\end{array}$ & $\begin{array}{l}97 \cdot 1 \\
93.3 \\
90.2 \\
87.6 \\
93.3 \\
95.9 \\
92.4 \\
94.2\end{array}$ \\
\hline
\end{tabular}

Mean $\%$ recovered by Si estimation method

Mean $\%$ recovered by determination of total lipid weight

$=93.0+1.0$

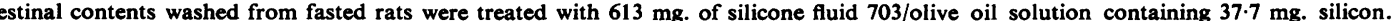
After evaporation and extraction with petroleum ether (b.p. $40^{\circ}-60^{\circ}$ ) recovered total lipid and silicon were evaluated experimentally.

similar to that obtained with olive oil alone. This demonstrates that the method of estimation of silicon is not interfered with by the presence of small amounts of phosphates such as are to be found after peroxide fusion of gastrointestinal and liver lipids (containing phospholipids).

The extraction of lipid material and silicone fluid 703 from the gastrointestinal tract by a dry extraction procedure utilizing petroleum ether (b.p. $40-60^{\circ} \mathrm{C}$.) as solvent led to the recovery of $92.6 \%$ of lipid material and $93 \%$ of the silicone fluid 703 was recovered at the same time (Table 3). When diethyl ether was employed as solvent in a continuous liquid-liquid extraction procedure (Paul, $1958), 86.5 \%$ of the lipid material but only $71.6 \%$ of the organosilicon compound was recovered.

Absorption of DC Silicone Fluid 703.-The methods of investigation employed in the study of the absorption of silicone fluid 703 from the gastrointestinal tract of rats were:-

(1) Examination of the chyle after feeding of the test material;

(2) Determination of the amount of fed material that could be recovered from the stomach, intestine, and caecum three hours after administration of the compound;

(3) Examination of the urine after long-term feeding experiments lasting several days.
Determination of the silicon content of intestinal lymph lipid from animals to which silicone fluid 703 had been fed as a solution in olive oil showed that no significant amount of silicone was absorbed along this route (Table 4). Infra-red studies on these lymph lipids from silicone-fed animals showed the absence of the organosilicon compound since these spectra were similar to those of fasting lymph lipids. The infra-red absorption method is only capable of detecting $5 \%$ of the organosilicon compound (Paul, 1958).

That fat was being normally absorbed during these experiments was demonstrated by the fact that when the mixture fed was coloured with $\beta$-brown, a dye-stuff known to be absorbed in oil solution, the lymph lipids were markedly coloured.

The results of the three-hour acute feeding experiments (Table 5) showed that only $84.5 \%$ of silicone fluid 703 was recovered from the gastrointestinal tract, whereas $71.8 \%$ of the olive oil fed had been absorbed. When the washed intestines of the silicone-fed rats were homogenized and their lipid content extracted and examined no silicone fluid was found in the intestinal mucosa. These results are difficult to interpret as balance studies since $100 \%$ of the silicone fluid was not recovered. However, a consideration of the results of Table 2 indicates that in the method of silicon estimation there is for any single determination $-1 \cdot 1 \%$ biased

TABLE 4

ANALYSIS OF CHYLE LIPID FOR SILICONE FLUID 703 AFTER FEEDING 610.0 MG. OF A $15 \%$ SOLUTION IN OLIVE OIL

\begin{tabular}{|c|c|c|c|c|c|}
\hline $\begin{array}{c}\text { Weight of } \\
\text { Olive Oil } \\
\text { in Food Fed (mg.) }\end{array}$ & $\begin{array}{l}\text { Silicon Content } \\
\text { in Material Fed } \\
\text { (mg.) }\end{array}$ & $\begin{array}{l}\text { Total Lipid } \\
\text { Extracted from } \\
\text { Chyle (mg.) }\end{array}$ & $\begin{array}{c}\text { Total } \\
\text { Si Content } \\
\text { in Chyle Lipid (mg.) }\end{array}$ & $\begin{array}{c}\text { Si Concentration } \\
\text { Recovered } \\
\%\end{array}$ & $\begin{array}{l}\text { Ratio of Lipid } \\
\text { Concentration fed } \\
\text { to Lipid Recovered }\end{array}$ \\
\hline $518 \cdot 5$ & $\begin{array}{l}35 \cdot 38 \\
(5.8 \%)\end{array}$ & $\begin{array}{r}91.0 \\
125.4 \\
69.0 \\
90.9 \\
34.7 \\
95.0 \\
71.0\end{array}$ & $\begin{array}{l}0.12 \\
0.33 \\
0.15 \\
0.28 \\
0.12 \\
0.44 \\
0.21\end{array}$ & $\begin{array}{l}0.13 \\
0.26 \\
0.22 \\
0.31 \\
0.35 \\
0.46 \\
0.30\end{array}$ & $\begin{array}{l}51 \cdot 8 \\
25.9 \\
31 \cdot 4 \\
22.2 \\
19.7 \\
14.7 \\
23.1\end{array}$ \\
\hline
\end{tabular}


TABLE 5

THREE-HOUR ACUTE FEEDING EXPERIMENIS WITH DC SILICONE FLUID 703 IN OLIVE OIL

\begin{tabular}{|c|c|c|c|c|c|c|c|c|c|}
\hline \multirow{2}{*}{ Group* } & \multicolumn{3}{|c|}{ Weight of Lipid Recovered from } & \multirow{2}{*}{$\begin{array}{l}\text { Weight of } \\
\text { Triglyceride } \\
\text { Absorbed }\end{array}$} & \multirow{2}{*}{$\begin{array}{c}\% \\
\text { Triglyceride } \\
\text { Absorbed }\end{array}$} & \multicolumn{3}{|c|}{ Weight of 703 Recovered from } & \multirow{2}{*}{$\begin{array}{c}\% 703 \\
\text { Recovered }\end{array}$} \\
\hline & $\begin{array}{c}\text { Stomach } \\
\text { (mg.) }\end{array}$ & $\begin{array}{l}\text { Intestine } \\
\text { (mg.) }\end{array}$ & $\underset{(\mathrm{mg} .)}{\text { Caecum }}$ & & & $\begin{array}{c}\text { Stomach } \\
\text { (mg.) }\end{array}$ & $\begin{array}{c}\text { Intestine } \\
\text { (mg.) }\end{array}$ & $\begin{array}{c}\text { Caecum } \\
\text { (mg.) }\end{array}$ & \\
\hline $\mathbf{A}$ & $\begin{array}{r}21.0 \\
20.7 \\
63.9 \\
3.4\end{array}$ & $\begin{array}{c}167 \cdot 8 \\
138 \cdot 6 \\
186 \cdot 0 \\
134 \cdot 7\end{array}$ & $\begin{array}{l}11.6 \\
25.3 \\
39.6 \\
30.2\end{array}$ & $\begin{array}{l}413 \cdot 1 \\
426 \cdot 0 \\
319 \cdot 0 \\
443.2\end{array}$ & $\begin{array}{l}80 \cdot 6 \\
83 \cdot 1 \\
62 \cdot 2 \\
86 \cdot 5\end{array}$ & $\begin{array}{l}4.09 \\
3.52 \\
9.96 \\
-\end{array}$ & $\begin{array}{l}95.99 \\
93.86 \\
77.45 \\
91.20\end{array}$ & $\begin{array}{l}0.53 \\
0.97 \\
8.17 \\
7.4\end{array}$ & $\begin{array}{l}87 \cdot 8 \\
87 \cdot 9 \\
83 \cdot 3 \\
85 \cdot 9\end{array}$ \\
\hline $\mathbf{B}$ & $\begin{array}{r}135.5 \\
39.5 \\
29.9\end{array}$ & $\begin{array}{l}226 \cdot 4 \\
222 \cdot 2 \\
175 \cdot 6\end{array}$ & $\begin{array}{r}50 \cdot 5 \\
2 \cdot 5 \\
26.0\end{array}$ & $\begin{array}{l}180 \cdot 8 \\
341.4 \\
749.5\end{array}$ & $\begin{array}{l}39 \cdot 6 \\
74 \cdot 7 \\
76 \cdot 4\end{array}$ & $\begin{array}{l}34.99 \\
6 \cdot 27 \\
6 \cdot 66\end{array}$ & $\begin{array}{l}90 \cdot 1 \\
123 \cdot 8 \\
113 \cdot 7\end{array}$ & $\frac{10 \cdot 58}{3 \cdot 13}$ & $\begin{array}{l}86 \cdot 3 \\
81 \cdot 5 \\
78 \cdot 6\end{array}$ \\
\hline
\end{tabular}

Mean \% silicone fluid 703 recovered $=85 \pm 1 \cdot 2$

Mean \% olive oil absorbed $=72 \pm 5.7$

*Group A rats fed $0.65 \mathrm{ml}$. (627.27 mg.) of an $18.3 \% 703 /$ olive oil solution. This contained $114.8 \mathrm{mg}$. DC silicone fluid 703 .

Group B rats fed $0.65 \mathrm{ml}$. (614.6 mg.) of a $25.6 \%$ solution of 703 in olive oil. This contained $157.1 \mathrm{mg}$. of DC silicone fluid 703 .

TABLE 6

ABSORPTION OF DC SILICONE FLUID 703 IN LONG-TERM FEEDING EXPERIMENTS

\begin{tabular}{|c|c|c|c|c|c|c|c|}
\hline \multirow{2}{*}{$\begin{array}{c}\text { Total Silicon } \\
\text { Content in Food Consumed } \\
\text { (mg.) }\end{array}$} & \multicolumn{6}{|c|}{ Silicon Content Found in } & \multirow[b]{2}{*}{$\% 703$ Recovered } \\
\hline & $\begin{array}{c}\text { Gastrointestinal Tract } \\
\text { (mg.) }\end{array}$ & $\begin{array}{l}\text { Faeces } \\
\text { (mg.) }\end{array}$ & $\begin{array}{l}\text { Urine } \\
\text { (mg.) }\end{array}$ & $\begin{array}{l}\text { Liver } \\
\text { (mg.) }\end{array}$ & Kidney & $\begin{array}{c}\text { Fat } \\
\text { Depot }\end{array}$ & \\
\hline $\begin{array}{r}982 \cdot 8 \\
1058 \cdot 4 \\
961 \cdot 2 \\
1071 \cdot 0 \\
1063 \cdot 0 \\
1026 \cdot 0 \\
944.0\end{array}$ & $\begin{array}{l}\overline{1.48} \\
2.50 \\
\overline{-} \\
\overline{1.63} \\
-\end{array}$ & $\begin{array}{r}979.2 \\
1011.0 \\
929.9 \\
1001.0 \\
975.0 \\
1019.0 \\
898.0\end{array}$ & $\begin{array}{l}= \\
= \\
z \\
z\end{array}$ & $\begin{array}{l}E \\
z \\
z \\
-\end{array}$ & $\begin{array}{l}= \\
= \\
z \\
=\end{array}$ & $\begin{array}{l}= \\
= \\
z \\
=\end{array}$ & $\begin{array}{l}99.6 \\
95.7 \\
97.0 \\
93.4 \\
91.7 \\
99.5 \\
95.1\end{array}$ \\
\hline
\end{tabular}

Mean $\%$ silicone fluid 703 recovered $=96.0 \pm 1.0$

DC Silicone fluid 703 fed with olive oil and rat cake powder to seven rats for a period of eight days. Tissues and faeces were examined for organosilicon compound and urine for soluble silica.

No silicon was found in the lipids of the gastrointestinal tract, faeces, liver, kidney, or fat depot of control animals maintained on a diet of rat cake powder and olive oil.

error, so that when this determination is applied to the analysis of the gastrointestinal tract in three sections (stomach, intestine, and caecum) this error applies to each determination. Consideration of the results of Table 3 similarly show that in the extraction procedure used in these experiments only $93 \%$ of the total lipid and lipid soluble materials were recovered, i.e., $-7 \%$ biased error.

Table 6 contains the results of prolonged feeding experiments lasting eight days. Ninety-six per cent of the silicone fluid 703 fed was recovered, mainly from the faeces. No silicone fluid 703 was found

TABLE 7

FURTHER EXAMINATION OF LIVER LIPIDS AND LIPID MATERIALS FROM FAT DEPOTS, OBTAINED FROM EXPERIMENTAL ANIMALS MAINTAINED ON A DIET OF DC SILICONE FLUIL FOR EIGHT DAYS

\begin{tabular}{l|c|c|c|c}
\hline & $\begin{array}{c}\text { Weight } \\
\text { before } \\
\text { Chro- } \\
\text { matography } \\
\text { (mg.) }\end{array}$ & $\begin{array}{c}\text { Weight } \\
\text { after } \\
\text { Chro- } \\
\text { matography } \\
\text { (mg.) }\end{array}$ & $\begin{array}{c}\text { \% Silicon } \\
\text { Content in } \\
\text { Extracted } \\
\text { Lipid }\end{array}$ & $\begin{array}{c}\text { Silicon } \\
\text { Content in } \\
\text { Pooled } \\
\text { Lipid } \\
\text { (mg.) }\end{array}$ \\
\hline $\begin{array}{l}\text { Pooled liver } \\
\text { lipids }\end{array}$ & $722 \cdot 2$ & 80.8 & 0.02 & 0.14 \\
$\begin{array}{c}\text { Pooled lipid } \\
\text { from fat } \\
\text { depot }\end{array}$ & $861 \cdot 1$ & $33 \cdot 1$ & 0.01 & 0.09 \\
\hline
\end{tabular}

in any of the tissues examined. The soluble silica content of the urines of the silicone-fed rats and that of urines of control animals was identical. Chromatography on an alumina column of the pooled liver lipids from the silicone-fed rats, and subsequent examination of the eluent for the organosilicon compound confirmed the absence of DC silicone fluid 703 in the liver (Table 7). Similar results were obtained with pooled lipid from the fat depots of the experimental animals after removal of most of the triglyceride fat.

\section{Discussion}

These results demonstrate that silicone fluid 703 when fed in a fat vehicle is not absorbed to a measurable extent. The site at which the silicone is separated from the triglyceride is in the intestinal region where the triglyceride is rapidly absorbed concentrating the organosilicon in the residue. The question arises as to the mechanism involved in the separation of the silicone and the triglyceride vehicle. Paraffinic hydrocarbons, although possessing no reactive site in the molecule at which rupture can occur to effect a change akin to hydrolysis, are nevertheless readily absorbed when fed in a fat 
vehicle (Stetten, 1943). Silicone fluid 703 is similar to the paraffinic hydrocarbons in being chemically inert and oil soluble.

It is now generally accepted from the extensive work of Frazer, Schulman, and Stewart (1944) that fine emulsification is essential for the absorption of unhydrolysable fat. Their investigations have shown that the particle size for the absorption of a dispersed oil phase is critical. The particles must be less than $0 \cdot 5-0 \cdot 3 \mu$ in diameter to be absorbed via the lymphatic pathway. These workers have also demonstrated that the triple combination of fatty acids, monoglycerides, and bile salts is present in the intestinal lumen. This system can produce fine emulsification of this particle size.

Results have been obtained which demonstrate that the silicone-fluid-703-loaded oil has emulsified effectively (Paul, 1958). However, no quantitative data were obtained as to the particle size of these emulsions other than visual observations under a dark ground microscope. Comparison with similar emulsions made from olive oil alone showed the particle sizes of both emulsions to be similar.

The failure of absorption of silicone fluid 703 during the simultaneous absorption of the triglyceride vehicle would seem to imply that a mechanism is present which actively and selectively separates the triglyceride from the silicone fluid 703 . It must also be appreciated that the triglyceride and the silicone are fully miscible; thus the mechanism is distinguishing between two substances intimately mixed.

It has not been possible from our present investigation to obtain any direct evidence as to what this mechanism is, but further work is in progress.

We wish to thank Professor A. C. Frazer for his interest and helpful advice, the Midland Silicones, Ltd. for gifts of silicone fluid 703 , and the University of Birmingham for a postgraduate research grant to one of us (J.P.).

\section{REFERENCES}

Ahmad, B. (1931). Biochem. J., 25, 1195 .

Bentley, R. (1955). Ph.D. Thesis, University of Birmingham.

Bloom, B., Chaikoff, I. L., Reinhardt, W. O., Entenman, C., and Dauben, W. G. (1950). J. biol. Chem., 184, 1.

Bollman, J. L., Cain, J. C., and Grindlay, J. H. (1948). J. Lab. clin. Med., 33, 1348.

Borgström, B. (1951). Acta chem. scand., 5, 643.

Child, G.'P., Paquin, H. C., Deichmann, W. B. (1951). A.M.A. G. P., Paquin, H. C., Deichmann,
Arch. industr. Hyg., 3, 479.
R. P. (1936). Biochem. J., 30, 1630

Cook, R. P. (1936). Biochem. J., 30, 1630.

Daniel, J. W., Frazer, A. C., French, J. M., and Sammons, H. G. (1951). J. Physiol. (Lond.), 114, 26P.

Drill, v. A. (1954). Cited from Silicones for Use in Medicine. Midland Silicones, Ltd., London.

Foulger, J. H. (1927). J. Amer. chem. Soc., 49, 429.

Frazer, A. C., Schulman, J. H., and Stewart, H. C. (1944). J. 'Physiol.' (Lond.), 103, 306.

Kern, S. F., Anderson, R. C., and Harris, P. N. (1949). J. Amer. Pharm. Ass. sci. Ed., 38, 575 .

Kim, K. S., and Ivy, A. C., (1952). Amer. J. Physiol., 171, 302.

Largett, E., Blackstone, M., and Roth, J. (1950). U.S. Air Force Med. Service.

Parr, S. W. (1908). J. Amer. chem. Soc., 30, 764.

(1919). J. industr. Engng. Chem., 11, 230.

Paul, J. (1958). Ph.D. Thesis, University of Birmingham

Rowe, V. K., Spencer, H. C., and Bass, S. L. (1948). J. industr. Hyg., 30, 332.

Schwartz, M. C. (1941). Industr. Engng Chem. Anal. Ed., 13, 536.

Stetten, DeW. (1943). J. biol. Chem., 147, 327.

Tasker, R. R. (1951). J. Physiol. (Lond.), 115, 292. 